\title{
CRITIQUES OF PTOLEMAIC ASTRONOMY IN ISLAMIC SPAIN*
}

\author{
George SALIBA \\ Columbia University \\ National Humanities Center/Dibner Institute
}

\section{INTRODUCTION}

There is now an emerging consensus that the astronomy that preceded Copernicus had a lot to do with the kind of astronomy which was later proclaimed by him, and that the foundations of Copernican astronomy were already laid in major Muslim intellectual centers, with some particular significance to al-Andalus itself, but more importantly to the cities of the Muslim east. This should not be surprising to the students of Copernicus because they know very well at least the names of Jābir ibn Aflah (first half of the twelfth century), and al-Bitrūjī (Latin Alpetragius c. 1200), to mention only two Andalusian astronomers, were both well known to Copernicus, and some of their results were used by him either directly or through other Latin works which were based on them. The Copernican connection with the Eastern Muslim cities was discovered very recently and is still emerging.

In general then, I will focus in this paper on the astronomical activities that took place in the Muslim world before the sixteenth century, and try to show how those activities may have had a lasting effect on Renaissance Europe. In particular, I intend to focus on the Andalusian part of the Muslim world and on the contributions to astronomy that were made there, as well as on the debates that were generated and became part of the positive developments in astronomy that can be traced linearly from Spain to Copernicus.

\section{ANDALUSIAN ASTRONOMY DURING ISLAMIC TIMES}

It will not be prudent, nor helpful, that I should attempt, in this limited space, to give a comprehensive survey of the whole history of astronomy during that period.

*An earlier version of this paper was first delivered as a talk at the New York Academy of Sciences on 28, April 1993. Since then it has benefited greatly from the comments supplied by Professor Samsó to the first draft that was submitted to the Al-Qantara for publication. Needless to say, that the present author is still fully responsible for all the remaining mistakes and shortcomings. 
There are many important activities that took place during the seven centuries of Islamic Spain, and many important persons participated in those activities. I could not possibly give any of them a proper assessment that an intelligent survey would require. ${ }^{1}$ What I will do instead, is to isolate those astronomical activities which can be connected somehow with later Renaissance astronomy. In this fashion I hope to point to certain intellectual landmarks which can be considered as reference points in the development of the new Renaissance astronomy.

On the other hand, to isolate those Andalusian astronomical texts which can be shown to have had an impact on the new astronomy of Copernicus is not an easy task. Because as soon as we move into the area of texts, we begin to move into a relatively uncharted territory. What complicates the problem further is that most people working in this area have historically described the critiques of Ptolemaic astronomy in terms of eastern and western types of approaches. With very few exceptions the majority of those researchers have managed to propagate a general characterization of those critiques that took place in al-Andalus as being philosophical in nature, while those that took place in the east were mathematically oriented. The purpose of the Andalusian philosophers was to be restricted to finding alternatives to the Ptolemaic eccentrics and epicycles and not to question the general foundations of Greek astronomy. ${ }^{2}$ While the aim of the eastern astronomers was characterized as being concerned with straightening "out Ptolemaic astronomy by bringing it more in line with its own principles". ${ }^{3}$

What has been forgotten, or never stressed enough, is that this characterization was arrived at by contrasting mainly the works of a group of Andalusian philosophers with the works of a group of eastern astronomers. The Andalusian critiques of Ptolemaic astronomy that were studied were always focused on the works of the philosophers and never ventured to examine the works of the Ansalusian astronomers, for example, except in the case of al-Bịtrüjī whose work could in fact plausibly

\footnotetext{
${ }^{1}$ Preliminary surveys of this nature do exist and the reader could benefit immensely from consulting the latest by Samsó, J., Las Ciencias de los Antiguos en al-Andalus, Madrid, 1992.

${ }^{2}$ See, for example, Gauthier, L., "Une Reforme du Système Astronomique de Ptolemée tentée par les Philosophes Arabes du XIIe siècle», Journal Asiatique, 10e ser., 14 (1909), 483-510, where he argues that "ces réformeurs, nous dit-on, prétendaient substituer aux hypothèses de l'Almageste, qui depuis plus de mille ans régnaient sans partage, une hypothèse générale plus simple et plus conforme à la réalité, expliquant sans épicycles ni excentriques tous les mouvements célestes que révélait l'observation". In another article, and without referring to Gauthier, A. I. Sabra, in Chapter seven in Transformation and Tradition in the Sciences, edited by Everett Mendelsohn, Cambridge University Press, 1984, 133-153, seems to have reached the same conclusion when he states that iit is important to distinguish between this line of research [meaning that which was followed by the astronomers of the eastern part of the Muslim world] and what took place in Andalusia in the century separating Ibn al-Haytham and the Marāgha astronomers».

${ }^{3}$ Ibid.
} 
be studied as part of the Andalusian philosophical enterprise. As such the general characterizations that have been advanced so far have therefore managed to both skew the results of the research and to lead to predictable results, namely, that the works of philosophers were not similar to the works of astronomers. What was always lacking was a contrast between the works of astronomers on both sides of the Mediterranean divide.

Consequently, most of the mathematical astronomical texts which may have something to do with the critique of Ptolemaic astronomy and which were produced in al-Andalus have either remained in manuscript form or are yet to be located and identified. From that perspective, some of the results that will be announced in the sequel will be breaking new grounds, for they will bring to the attention of the reader reports from astronomical texts which were written in al-Andalus during the Islamic period, which have not been fully studied and digested, and which will demonstrate a continuity with the eastern astronomical works rather than a contrast. These results are now beginning to emerge and derive mainly from astronomical texts that were either unknown before or have not been given an attentive reading whenever they could be found. But as it will soon become clear, the available evidence is still very fragmentary in nature and it will take years before it is fully assimilated and incorporated into the general picture of the history of astronomy, and especially the history of astronomy in al-Andalus.

In order to put those astronomical texts that were produced in al-Andalus into their wider context, some preliminary remarks should be made at this point. The reader should be reminded that Arabic astronomy as a whole has often been characterized since the nineteenth century as a continuation of Greek astronomy. Those nineteenth-century historians of science and their followers, who obviously did not know any better, would even go as far as saying that the Arabic appropriation of Greek astronomy was accomplished in Islamic classical times mainly for the purposes of using that astronomy for practical astrological prognostications, and that the theoretical foundations of that astronomy were beyond the reach of Muslim astronomers. This was more or less the position held in general till the late 1950s. It is further regrettable that in our own days the same assessment still surfaces every now and then in secondary and tertiary sources dealing with Islamic intellectual history and is too ubiquitous to require particular documentation.

The late fifties however was a watershed in our knowledge of Islamic astronomy, because it was in 1957 that the distinguished historian of science, Otto Neugebauer, managed to demonstrate to his colleague Edward Kennedy of the American University of Beirut that the Arabic text that Kennedy had brought with him to Brown University in order to show it to Neugebauer did indeed contain a 
description of the lunar motions which was not found anywhere in the Greek sources. Moreover, Neugebauer demonstrated that the description of the lunar motions as preserved in the Arabic text of Ibn al-Shătir of Damascus (d. 1375), carried by Kennedy, was indeed identical to that which was proposed by Copernicus first in 1516, and later in 1549. The result of that encounter between Neugebauer and Kennedy engendered an article in Isis, titled "The Solar and Lunar Theory of Ibn al-Shātir: A Pre-Copernican Copernican Model», by Victor Roberts, one of Kennedy's students. ${ }^{4}$

This article was then followed by a group of other articles discussing the remaining astronomical results of Ibn al-Shātir, as well as the results of a group of related astronomers, collectively called the Marāgha School astronomers. Research on the activities of these astronomers is still going on, and more connections with Copernicus are surfacing everyday.

One can imagine the startling effect this research has had when it did not only demonstrate that Copernican astronomy was heavily indebted to its Arabic antecedents, but that Arabic astronomy itself was not a simple straightforward adaptation of Greek astronomy for the purposes of astrological predictions. In fact, no modern and well-informed student of Arabic astronomy can still defend the nineteenth-century position. On the contrary, recent research is now beginning to demonstrate that the Muslim astronomers, who worked in connection with the Marāgha School, had only a marginal interest in astrological prognostication, despite their declared purpose for the building of the Marāgha Observatory. Their main activity was specifically directed at criticizing and reformulating Greek astronomy. On that count, it is significant to note that the latest, most authoritative work on the mathematical astronomy of Copernicus, by Noel Swerdlow and the same Otto Neugebauer, refers to Copernicus as "the last of the Marāgha astronomers". ${ }^{5}$

What is more significant, however, is that we are now beginning to look for the philosophical foundations of Arabic astronomy and for the motivation behind that kind of innovative groundbreaking research which was carried out by the Marāgha astronomers and their followers. We are beginning to ask theoretical questions that we did not dare think of before. And we are beginning to see that Arabic astronomy did indeed harbor a long history of criticism of Greek astronomy and that the same criticism had left its mark on the works of most astronomers practicing during medieval Islamic times.

\footnotetext{
${ }^{4}$ Roberts, V., "The Solar and Lunar Theory of Ibn al-Shātir: A Pre-Copernican Copernican Model", Isis, 48 (1957), 428-432.

${ }^{5}$ Swerdlow, N., and Neugebauer, O., Mathematical Astronomy in Copernicus's De Revolutionibus, NY: Springer Verlag, 1984, 47, 295.
} 
Needless to say, this new research is beginning to force upon us questions regarding the background of the Marāgha School astronomers themselves and the relationship between their works and the works which were produced during the classical period of Islamic science. In that connection we are beginning to discover that Greek astronomy was indeed subjected to a very critical review at the hands of Arab astronomers as soon as that astronomy was translated into Arabic. At times, this critical review went hand in hand with the translation activity itself. ${ }^{6}$ We are also beginning to understand why the early astronomers decided to repeat some of the same observations which were already conducted in Greek classical times. But most importantly, we are beginning to understand the impact of Greek astronomy on early Islamic society once that astronomy was rendered into Arabic.

Modern research in Arabic astronomy can now defend the following position. Arab astronomers who had learned of Greek astronomy through the translations of the major Greek astronomical texts, most important of which was the Almagest of Ptolemy (fl. 150), began to notice early on that that astronomy had at least two kinds of problems. The first kind had something to do with the results which were reported by the Greek astronomical texts and which were not supported by the observations conducted in Islamic classical times. The second problem had to do with the inner consistency of Greek astronomy itself as a scientific discipline.

It was found that, although Greek cosmological doctrines underlying the mathematical formulation of Greek astronomy rested on physical bases, those same foundations were violated when the description of the behavior of the planets was expressed in mathematical terms. Naturally, a mathematical discipline like astronomy, as it was understood by the Greeks and later by the Muslim astronomers, could not harbor such obvious contradictions between the physical presuppositions of a science and the mathematical presentations of the results established in that science. In a sense, the revolutionary activities of the Marāgha astronomers seem to have centered around this second issue, and their main concern was to formulate a new astronomy that was not bedeviled by the same contradictions as Greek astronomy.

This aspect of their work was the one that invited the similarity with Copernican astronomy, for Copernicus too was trying to find an astronomy that was not plagued by the same contradictions. In fact, the reading of the introduction of Copernicus's earliest astronomical work, the Commentariolus, which was completed in 1516 and

\footnotetext{
${ }^{6}$ This has been recently demonstrated by the present author as having occurred as early as the ninth century. See, Saliba, G., «Early Arabic Critique of Ptolemaic Cosmology: A Ninth-Century Text on the Motion of the Celestial Spheres", Journal for the History of Astronomy, 25 (1994), 115-141.
} 
where Copernicus gives the reasons for his search for a new astronomy, almost three centuries after the Marāgha astronomers, sounds very much like the works of any of the Maragha astronomers. The major difference between the two is that Copernicus proposed a heliocentric theory for his new astronomy, while the Marāgha astronomers continued to assume a geocentric one. The mathematics of the two proposals remained essentially the same, for, mathemetically speaking, the difference between the two theories is a matter of reorienting one vector to shift the reference point from the earth to the sun.

It is the area of this new critical astronomy that the Andalusian contribution should be perceived. Modern historians of Arabic astronomy had already identified the key texts which were written in the eastern part of the Islamic world and in which a critical approach to Greek astronomy was clearly articulated. They date the maturity of this type of texts to the first half of the eleventh century when the famous astronomer, mathematician and physicist Ibn al-Haytham (Latin Alhazen) composed his famous work al-Shukük 'alä Batlamyūs (Doubts regarding Ptolemy). ${ }^{7}$ In that work, Ibn al-Haytham did indeed take Ptolemy, the author of the Almagest (the most important Greek astronomical work), to task and condemned the astronomy proposed by him in no ambigous terms, specifically because that astronomy seemd to Ibn al-Haytham to have harbored a contradiction between its physical and mathematical presuppositions. A new astronomy, Ibn al-Haytham said, must be found that describes the real universe in mathematical terminology that did not imply the contradictions that one sees in Greek astronomy. Other astronomers seem to have written works similar to Ibn al-Haytham's Doubts, but none of them has come to light so far. The work of the Marăgha astronomers is seen in that context as a fulfillment of the task which was only proposed by Ibn al-Haytham.

As far as the western front of the Muslim world is concerned, in al-Andalus, the prevailing wisdom asserts, as was previously noted, that such a program as that of Ibn al-Haytham was not enunciated, and the likes of the Marāgha astronomers were generally not found. Instead, the contribution of the Andalusian school was perceived as being more of a philosophical nature, in the sense that while in the east the criticism was directed at the adequacy of the Greek mathematical models, in the west it was directed only at the philosophical underpinnings of those models.

Of course, from a methodological point of view, once such generalizations were formulated they tended to drive research in specific directions and to

${ }^{7}$ Sabra, A. I. and Shihābī, N., al-Shukuk 'alā Batlantyūs (Dubitationes in Ptolemaeum), Cairo: Dār al-Kutub, 1971. 
produce specific mind sets that could no longer see outside that framework. As a result, texts were often misinterpreted, and much was lost in the process.

The present author's research on astronomical texts that were written in alAndalus can now support the following tentative conclusions: First, one can assert that there were texts that were written in al-Andalus, which were similar to the works of Ibn al-Haytham and his Marāgha followers in the east. And second, it can be argued that even the so-called Marāgha astronomers had their own philosophical objections to Ptolemaic astronomy that were articulated in exactly the same language that was used by the Andalusian philosophers. The underlying thesis that emerges is that one could demonstrate the fallacy of the dichotomy drawn between eastern and western schools of thought as far as the critiques of Ptolemaic astronomy were concerned, and one can confirm more avenues of continuity than was perceived before.

Those conclusions can be based on two main texts. The first is a text, called Risalat al-Hay'a (A Treatise on Astronomy), that was discovered in a manuscript copy by the present author on his first trip to Hyderabad, India, in the early eighties, and the second is the text of the Damascene astronomer Ibn al-Shạtir himself who has been mentioned before as a predecessor of Copernicus.

\section{RISĀLAT AL-HAY’A}

The manuscript copy of Risalat al-Hay'a is kept at the Osmania University Library in Hyderabad, ${ }^{8}$ and its subject matter is not of any great importance, since it consists of a simple elementary introduction to astronomy as it was known from the Greek sources. In addition, the manuscript is very poorly preserved, and erroneously identified as being an Arabic copy of Ptolemy's Planetary Hypotheses. ${ }^{9}$ The false identification has led modern bibliographers such as Fuat Sezgin of Frankfurt to commit the same error and to attribute the manuscript to Ptolemy as well. But anyone who cares to read the text will quickly realize that it couldn't be farther from Ptolemy's Planetary Hypotheses, of which there are extant copies. ${ }^{10}$

Just like all mysterious manuscripts, the Hyderabad text is missing the beginning, about one or two pages, and the end, probably a chapter of five to six pages if not less. As a result we do not know the author, nor do we know the date

\footnotetext{
${ }^{8}$ The shelf number of that manuscript at the Osmaniya University Library is $520 \mathrm{RH}$.

${ }^{9}$ In fact the text is identified on the flyleaf with the following designation: kitäb al-iqtișass li-lBatlamyūs (sic), presumably meaning The Planetary Hypotheses of Ptolemy.

${ }^{10}$ See Goldstein, B., "The Arabic Version of Ptolemy's Planetary Hypotheses", Transactions of the American Philosophical Society, 57 (1967), 1-55.
} 
in which the text was copied, nor do we know the date of the original composition. The only recourse to the identity of the author had to come from the inner analysis of the text itself. From that analysis, the present author was able to determine that the author of Risälat al-Hay'a was an Andalusian who must have lived during the eleventh century.

Since this text is not well known, its contents are worth mentioning at this point. It is divided into four main sections, called fanns. The first fann is devoted to a general statement of the principles of astronomy, arranged in fourteen elementary chapters, and covers folios 1-16. The second deals with the relative position of the earth with respect to the celestial sphere. This one too is divided into fourteen chapters, and covers folios 17-30. The third is the main portion of the treatise, and is devoted to the conditions of the planets (Ahwäl al-Kawäkib), which are treated in forty one chapters covering folios 31-85. The last fann, in nine chapters covering folios $86-94 \mathrm{v}$, is incomplete, lacking the ninth chapter, and concerns itself with the observed variations resulting from the positions of the planets with respect to each other, and with respect to the earth. It deals, in an elementary fashion, with such issues as parallax, apparent diameters of the two luminaries, and planetary distances and sizes.

One could have dismissed this treatise as being too elementary to deserve any attention, except that it comes from al-Andalus, where as far as is known no other treatise carries the term Hay'a in its title except that of Bitrūjīi, and of Jābir according to at least one manuscript tradition (Escorial Arabic 910). It could have also been dismissed had it not been for the other more important work, by the same author, that it referred to every now and then, and which has not yet been located. Therefore the interest in this Hyderabad Hay'a text at this point focuses on this other yet-to-be located text, which was referred to as Kitäb al-Istidräk, and which I presume from the type of references that it was probably called Kitäb alIstidräk 'alä Batlamyūs (Recapitulation in Regard to Ptolemy), if it ever existed.

\section{AUTHORSHIP OF THE ISTIDRĀK}

The evidence that was used to determine the circumstances of the authorship of al-Istidräk was rather straightforward. In chapter fourteen of the first fann of the Hay'a text, called fì kayfĩyat al-arșäd wa-l-älāt al-muttakhadha lahä 'alä tarīq al-ikhtisāar wa-l-ijmäl, freely translated as On the Methods of Observation and the Instruments Adopted for them in a Summary Fashion, the author goes on to discuss the various conditions that could produce faulty observations. Among 
those conditions, he mentions the instability (takhalkhul) of the instruments themselves. And then he says that this condition in specific had occurred in Damascus during the time of al-Ma'mūn", and "has happened in the city of Toledo, of Andalusia, with the instrument which was set up in it, as I was told by the one who conducted observations with it, Abū Isḥāq Ibrāhīm ibn Yạ̣yā known as Azarquiel» (fol. 15v). ${ }^{11}$ The Arabic text (Figure 1, lines 3-6 right) reads: $k a-l$ ladhì 'arada bimadīnati Ṭulaytila min bilādi al-Andalusi fĩ-l-älati al-latī nușibat bihā, 'alā mā akhbaranī mutawallī al-rașda bihā Abū Ishāqa Ibrāhimu bnu Yahyāal-ma'rüfu bi-l-Zarqiyel. The second time the author mentions Azarquiel, is in the context of the value for the inclination of the ecliptic, where he says that Azarquiel had found it to be etwenty three parts, thirty three minutes, and eight seconds" (fol. 17r). But he does not say that he learned that from him personally, as he had said in the first instance.

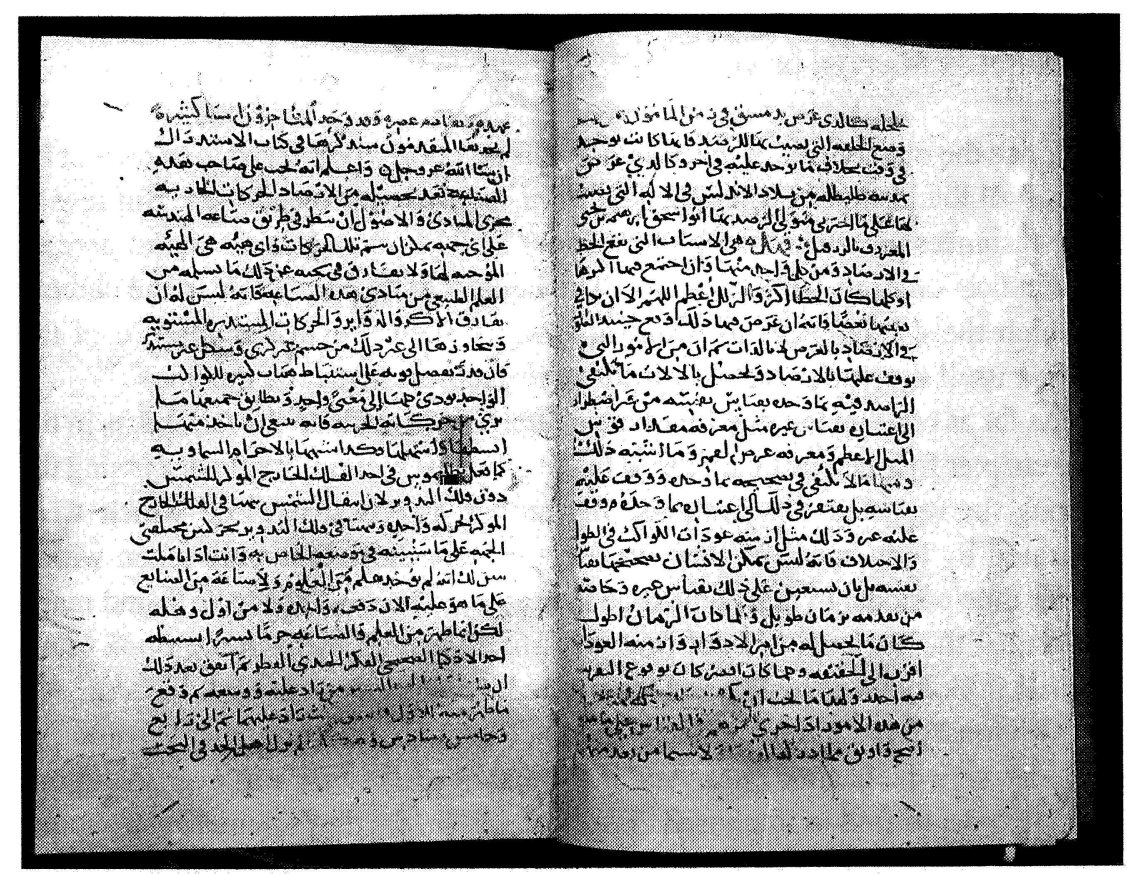

Figure 1.- Folios 15v-16r of Risalat al-Hay'a. Courtesy of the Osmania Library, Hyderabad (Deccan).

11 The name of this astronomer has been variously transliterated, most commonly, depending on etimological arguments, as Azarquiel or al-Zarqālluh (mentioned by Prof. Samsó in his comments to the author). Marking only consonants, the Hyderabad text has 'Izrqyl, while Ibn al-Hā'im has the usual spelling common to western Arabic manuscripts of the name 'Izrqālh/t, and Mu'ayyad al-Dīn al-'Urḍī has twice 'Izrqālh/t, 81, 82, and once 'Izrqãl, 135. 
Nevertheless, the first quotation leaves no doubt as to the location of the author, or his time. Azarquiel is not known to have traveled outside al-Andalus, and he is known to have lived during the last three quarters of the eleventh century. If both claims are true, and there is no reason why they should be doubted, then the author of al-Istidräk was a contemporary of Azarquiel, who must have met Azarquiel, and must have therefore lived in al-Andalus in the eleventh century.

It is unfortunate that we cannot at this point derive any more information about his identity. A cursory glance at the list of astronomers who lived in alAndalus during the same period can be extensive, but none of them is known to have authored either a treatise referred to as a Hay'a text, or a counter-Ptolemaic text called Istidräk. More on this issue below.

\section{THE SUBJECT MATTER OF AL-ISTIDRĀK}

Since the manuscript of the Hay'a text is so poorly preserved, one cannot be sure of all the instances when the text of al-Istidräk was mentioned. But few of those instances are clear enough to warrant a closer examination and to give us some indication of its subject matter. The interest at this point lies in the context in which these references to Kitäb al-Istidräk occur for in the absence of the Istidräk itself they offer the only leads to the subject matter of the book.

As far as one can tell, the first time a reference is made to the Istidrak is in the same chapter fourteen just mentioned in the previous section. While discussing the reasons for repeated observations, the author asserts that those which were separated by long spans of time were better than those that were taken within shorter time periods. In that context he then says: "The moderns have found many things that the ancients did not find. We shall mention them in the Book of alIstidräk if God, the almighty and the exalted, so wills it" (fol. 16r).

Obviously, the ancients here stood for Ptolemaic astronomers, while the moderns were the Islamic ones. And if the text of al-Istidräk was ever found one would expect to find in it a host of issues at variance with Ptolemaic astronomy. However, this quotation also seems to indicate that the book of al-Istidräk was not yet written, when the Hay'a text was completed.

The second time the Istidräk was mentioned was in chapter five of the third fann, which was devoted to the determination of the solar eccentricity and solar apogee. In the context of a discussion involving the solar apogee, and after saying that Ptolemy had found the solar apogee to be fixed, the author went on to say: 
"As for the moderns, when they examined that, they found it at great variance, and thus concluded that the apogee must move, for they found it to be at the time of al-Ma'mūn's caliphate at twenty degrees and about two third of a degree in Gemini. These matters should be considered carefully (fī hädhihi al-ashya $\bar{a}$ nazarun), and they ought to be mentioned in al-Istidräk" (fol. 41v). So the Istidräk must have also contained a discussion of the moving solar apogee in contradistinction to Ptolemy's opinion.

The last time al-Istidräk is mentioned, as far as it can be told, is in chapter nine of the same third fann, where the discussion of the lunar spheres was taken up. There, after expounding on the Ptolemaic model for the moon, the author said: "One could object to ( $u^{\prime}$ ridu / a'taridu 'ala) Ptolemy in many ways regarding these motions. But they ought to be mentioned in what is simpler? (absat) than this book. I shall mention them in al-Istidrak, if God, the almighty and the exalted, so wills it» (fol. 48r). This leaves no doubt that al-Istidrak must have included a discussion of problems similar to those which were raised by Ibn al-Haytham and the Marāgha astronomers against the Ptolemaic lunar model. One can also imagine that both the problem of the equant as well as that of the prosneusis would have figured very prominently in that discussion. For this reason, one would not expect the equant problem, that is well known from the Ptolemaic model for the upper planets, to have been given any special treatment on its own. In fact, this seems to have been the case for in the Hay'a text the author did not repeat his promise to mention the equant in the Istidrak, or if he did it would be very difficult to locate.

\section{THE PURPOSE OF AL-ISTIDRĀK}

Since the extant data regarding this apparently lost work is so fragmentary in nature, one can only speculate about the purpose of al-Istidräk. Besides mentioning the drawbacks of Ptolemaic astronomy, as in the instances of the solar apogee and the ecliptic inclination, one can imagine that the book would have in addition contained the new astronomical findings which were made during Islamic times. One would have also certainly expected the author to examine very carefully the contradictions implied by the Ptolemaic models in regard to such concepts as equants and prosneusis, as he has so explicitly promised at the end of the chapter on the moon.

But one would not have expected this author to have raised much fuss about the problems of the eccentrics and the epicycles. In that respect he would have followed the same tradition that was followed by his compatriot Jãbir Ibn Aflah, 
or that was followed by the majority of the Marāgha astronomers. It is almost certain that he, like the Marāgha astronomers, would have been worried about the problems of inner consistency of any new models he would propose, if he ever did, in al-Istidräk but would not express opinion on epicycles and eccentrics. In the Hay'a text, and in the same concluding chapter fourteen of the first fann, he had this to say: "You should know, that the practitioner of this art $\left(\sin \bar{a}^{\prime} a\right)$, after having extracted from the observations the motions that are like the principles and the foundations, he should then seek from the art of geometry (sina' at alhandasa) the manner in which these motions could be achieved, and which configuration (hay'a) would be the one necessitating them. While searching for that, he should not deviate from that which he has accepted from the physical sciences ( $a$ - 'ilm $a l-t a b \bar{\imath}^{\prime} \bar{\imath}$ ) by way of foundations (mabädi') for this art. He should not abandon the spheres, the circles, and the circular uniform motions, and pass on to other than that like non-spherical bodies, or non-circular figures. If by virtue of his power he was able to discover (istinbāit) many configurations (hay' $\bar{a}$ ) for each planet (text has planets), all of them leading to the same result, and all of them in perfect accord with the observable particular motions, then he should opt for the simplest and most facile and that which resembles the celestial bodies as was done by Ptolemy when he opted for the eccentric in the case of the sun and not the epicycle" (fol. 16r). Then he went on to say that uif one were to ponder one would find that none of the sciences ('ilm min al-'ulüm), nor any of the arts $\left(\sin \bar{a}^{-} a \min a l-\operatorname{san} \bar{a}^{-} i^{\prime}\right)$ were ever found as they were then from the very beginning" (fol. 16r, Figure 1, left, lines 18-20). ${ }^{12}$

Obviously, one had to work continually on the astronomical science in order to rid it of such pitfalls as the ones already mentioned in the Hay'a text and promised in the Istidräk. The spirit of that inquiry was in no way different from the program repeated so many times by the Marāgha astronomers. More pertinent to this discussion is that this spirit was obviously found in eleventh century alAndalus, just about the same time when Ibn al-Haytham of Egypt (d. 1038), and Abū 'Ubayd al-Jūzjānī (c. 1070) in the east were voicing similar concerns about Ptolemaic astronomy.

${ }^{12}$ This is almost the very same statement of the Marāgha astronomer 'Urdī (d. 1266), when he said: "Each science or art ('ilm $a w \sin \vec{a} a$ ) is rarely found to be perfect from the very beginning, without any blemish, where the initiator would have reached with it the ultimate aim that could no longer be corrected or added to -especially this noble art [meaning astronomy] and its ambiguitys. See The Astronomical Work of Mu'ayyad al-Din al-'Urdit' A Thirteenth Century Reform of Ptolemaic Astronomy, ed. and introduction by George Saliba, Beirut: Markaz dirāsāt al-Waḥda al'Arabīya, 1990, 228. 
Of greater importance still is the inevitable conclusion that the Andalusian author was obviously well informed about the latest achievements of Arabic astronomy either through his own participation in the production of such astronomy or through his contacts with the famous astronomers of his day, such as Azarquiel, who was himself critical of Greek astronomy for his own reasons.

This is not a trivial finding, for it makes the eleventh century a rather active century in which a very serious debate was taking place in the Islamic world -both east and west- regarding the inherited Greek astronomy and the new "progressive" Arabic astronomy. As we have just seen, the new astronomy must have laid a much greater emphasis on observations than on the received word of the masters. Such an attitude is usually associated with the much more advanced stages of scientific development. And here we find it in the eleventh century, not only expressing itself in raising doubts against the theoretical foundations of Greek astronomy, but also proposing to correct them on the basis of the new observational results. Most importantly, the explicit discussion of the reasons that could cause errors in observations were also discussed during this century. In that regard, al-Andalus was in no way different from the rest of the Muslim world where such problems were also being raised and discussed just about the same time. And if the critical spirit and the new scientific advances were responsible for ushering in the later Renaissance, then it is in such areas that the seeds for that Renaissance were indeed sown.

\section{THE PHILOSOPHICAL QUESTIONS OF IBN AL-SHĀṬIR}

The second text that can be used in support of the conclusions enunciated earlier regarding the similarities between the philosophical questions that were raised in al-Andalus as well as in the eastern parts of the Islamic world is the text of Ibn al-Shătir. ${ }^{13}$ What this text seems to illustrate is that Ibn al-Shătir was also quite aware of the debate that had gone on in the Andalusian School of philosophy, and that his alternative models represented a successful attempt to resolve the problem of the eccentrics that was so vehemently attacked by the Andalusian philosophical school. As for the problem of the epicycles, he also had some very important contributions to make.

${ }^{13}$ The text intended here is Nihayat al-Sul fïTașhin al-Ușul (The Ultimate Quest regarding the Rectification of [Astronomical] Principles). A critical edition by the present author, using all the extant manuscripts, is forthcoming. All references are made to the pagination of the forthcoming edition. 
First, Ibn al-Shạtir's models were strictly geocentric, that is they assumed that the earth was indeed at the center of the world, and consequently was itself the center of heaviness. The fact that he indeed took this same philosophical position as the Andalusian philosophers was very clearly stated in his condemnation of the Ptolemaic concept of eccentrics, where in the second chapter of the Nihaya, during the discussion of the doubts and impossibilities (muhäalat) which were found in the commonly accepted Ptolemaic astronomy, he said: "Of these (i.e. doubts and impossibilities), the eccentric sphere (al-falak al-khärij al-markaz), if it encompasses the center of the world, it is impossible, for according to this there would have to be non-circular non-moving figures within the spheres encompassing the center of the world. If they (i.e. non-moving figures) were to move around the center of the world, then void would have to exist. If, on the other hand, the eccenter were to move uniformly around its own center, then there would be non-uniform motions around the center of the world. If that were to be admitted, then there would be no need for positing any spheres, and we would rather say that each planet has one sphere that moves it non-uniformly so that it becomes stationary, speeds up and slows down; and that is impossiblem. ${ }^{14}$

Clearly, Ibn al-Shạtir had accepted the same Aristotelian position which was advocated by the Andalusian philosophers about two centuries earlier. In that sense, he was indeed different from the rest of the Marāgha astronomers. But he was also different from the Andalusian philosophers, in that he was able to propose a mathematical model that did not include any eccentrics.

Second, only in the matter of the epicycles, did Ibn al-Shătir depart from the Andalusian philosophers. Not because he thought that epicycles were acceptable without discussion, but because he claimed that they represented a pseudoproblem, for indeed Aristotle himself would not have been able to completely rule out their existence.

"In the matter of the sun - Ibn al-Shătir said— the epicyclic sphere was possible $\left(j \bar{a}^{\prime} i z\right)$, except that it did not agree very well with strict observations as you shall see in the configuration (hay'a) of the sun.. ${ }^{15}$

\footnotetext{
${ }^{14}$ Ibn al-Shătir, Ultimate Quest, op. cit., 7. This position is reminiscent of that of 'Urḍi, who objects to Ptolemy by saying: «If we were to accept that a sphere could move around its own center sometimes slowing down, while at other times speeding up, then we would have no need for all that they have espoused in the matter of astronomy" (p. 135). See also p. 218, where he says: «If one were to accept this impossibility in this art, then it would all be in vain, and there would be no need for more than one concentric sphere for each planet, and anything anyone would say that it has an eccentric sphere or an epicycle would be a useless addition".

${ }^{15}$ Ibid.
} 
But more generally, he confronted the pseudo-problem of the epicycles in the following fashion. He first stated categorically that «the existence of small spheres, like the epicyclic spheres, which do not encompass the center of the world, is not impossible (ghayr mumtani ${ }^{\prime}$ ) except in the ninth sphere. The proof for this is that since each sphere has a planet and the eighth has several spherical stars, each of which is larger than some of the epicycles of the planets, and since the star (or planet kawkab) is different from the rest of the sphere, then the existence of epicyclic spheres and the like would not be impossible. One understands by that the spheres have some form of composition (tarkib $\left.b^{u n} m a\right)$. Only the ninth is absolutely simple (basit ${ }^{u n}$ mutlaq) and one cannot imagine in it an epicycle or a star». ${ }^{16}$

Later on he returned to this very point when he discussed accidental motions (al-harakät al-'aradìya) at the end of chapter six of the Nihäya, where he said: "They have agreed in regard to the permissibility of the epicycles in other than the ninth sphere, on account of the stars which we see in the spheres. The star in a sphere must indicate some form of composition $\left(\operatorname{tarkib} b^{u n} m a\right)$. And whoever says that the spheres are simple, and epicycles could not exist in them, and if there is a motion which is not around the center then it would not be simple, I would say that both the epicycles and their motions have been confirmed in existence (ta'ayyan wujūd al-tadāwir wa-harakätuha). If that were to be denied with indelible proof, then the composition of the spheres and their non-simplicity would be confirmed. In my opinion they are composed of simples not of elements, with the exception of the ninth (sphere), and God knows the truth". ${ }^{17}$

What Ibn al-Shạtir was clearly saying was that since Aristotle could not explain away the existence of the stars in any of the spheres, and that implied a contradiction in regard to the composition of the spheres, then he, Ibn al-Shạtir, would allow the epicycles, which were mostly much smaller than the stars, and would say that they were of the same nature as the stars. From that perspective the problem of epicycles would then become a pseudo-problem.

When read as such, the text of Ibn al-Shātir would illustrate the kind of philosophical questions that were being raised in the eastern parts of the Islamic world, but would also illustrate that there was no essential difference between the eastern tradition and the western tradition as far as the criticism of the Ptolemaic tradition was concerned.

\footnotetext{
${ }^{16}$ Ibid., $12-13$.
}

${ }^{17}$ Ibid., 35. 


\section{ANDALUSIAN ASTRONOMY IN THE TWELFTH AND THIRTEENTH CENTURIES}

The following section is a further attempt to refine the current research concerning the identity of the author of Kitab al-Istidräk and the kind of questions he seems to have raised in al-Andalus that were in their turn pertinent to what was to come later on during the Renaissance. In that respect this anonymous astronomer seems to have played a seminal role.

As far as his identity is concerned, it has been amply demonstrated that he was a contemporary of Azarquiel and that he was obviously on good terms with him. It is therefore natural that one should look for him among Azarquiel's students, or his successors who continued his line of research, hoping that at least one of them would mention our critical astronomer by name. So far, research has not yet reached that happy conclusion. But some preliminary results have already been established.

Among the astronomers who based their works on the observations of Azarquiel there was an astronomer by the name of Abū al- 'Abbās al-Kammād, first half of the twelfth century. ${ }^{18} \mathrm{He}$ apparently composed more than one book on astronomy. Among those books, one was called al-Kawr 'alä al-Dawr, which is hard to translate into English, for it says something like "The Return to the Cycle", whatever that means. He was also supposed to have authored two other similar works, one named al-Amad 'alä al-Abad, also difficult to translate for it means something like "The Endless Time», and al-Muqtabas "The Derived» to mean that the text was derived from the other two just mentioned. Unfortunately, none of these texts has survived in the original Arabic as far as we can tell. A Latin translation of some of those works seems to have existed and have received some attention. ${ }^{19}$

Al-Kammād's first text, however, that is his al-Kawr 'ala al-Dawr, was of special importance because it was used by a later astronomer of Seville by the name of Abū Muḥammad 'Abd al-Ḥaqq al-Ghāfiqī al-Ishbīlī , known as Ibn alHā'im (c. 1200). Ibn al-Hā'im says that he composed his own book, al-Kämilf $\bar{\imath}$ al-Ta'älìm (The Perfect [book] in the Mathematical Sciences), specifically in

\footnotetext{
${ }^{18}$ Brockelmann, C., Geschichte der arabischen Literatur, Leiden: Brill, 1937-1949, Supplement I, 864, says that he died in 1195 A.D. but that does not seem to be supported. See, for example, Sams6, J., Las Ciencias, 320-326, where he places this astronomer in Cordova around the year 1116-1117 (I owe this reference to the comments of J. Samso on the first draft of this paper).

${ }^{19}$ Millás Villacrosa, J., Estudios sobre Azarquiel, Madrid/Granada: n.p. 1943-1950, 346. See also, Chabás, J., and Goldstein, B., «Andalusian Astronomy: Al-Zîj al-Muqtabis (sic) of Ibn al-Kammād”, Archive for History of Exact Sciences, 48 (1994), 1-41 (I owe this reference to the comments of Samsó). See also, Mancha, J. L., "Ibn al-Kammād's Table of Trepidation", Archive for History of Exact Sciences, 52 (1998), 1-11.
} 
order to correct the mistakes found in the works of al-Kammād. The text of Ibn al-Hā' $\mathrm{im}$, which is used here, is preserved in an apparently unique copy at the Bodleian Library of Oxford, as far as one can tell. ${ }^{20}$ In a marginal way, Ibn alHă'im says that he decided to attack the works of the earlier astronomer alKammād, specifically because al-Kammād's errors were beginning to cause people to doubt the observations upon which those works of al-Kammād were based, namely the Toledan observations of Azarquiel and another astronomer by the name of 'Abdallāh Ibn Barghūth. ${ }^{21}$ The fact that Ibn al-Hā'im mentions Ibn Barghūth in the same context with Azarquiel is reason enough to make Ibn Barghūth a possible candidate for the authorship of al-Istidräk, which we are after. But he is not the only astronomer mentioned by Ibn al-Hā'im, nor was Ibn Barghüth the only astronomer of the eleventh century who could have authored such a text. Others referred to by Ibn al-Hā'im such as Abū Marwān al-Istijjī (first half of the eleventh century ${ }^{22}$ may also be candidates for the same authorship.

From other sources, such as Ṭabaqāt al-Umam of the Judge Șā'id al-Andalusī (1070), who was himself a respectable astronomer and a contemporary of Azarquiel, we also know of several people who lived during the eleventh century and who also could have authored such a book as the Istidräk. In this context, it is significant that Șā'id not only mentions an astronomer by the name of Ahmad b. 'Abdallāh b. al-Șaffār (fl. c. 1050), who may have been the author of alIstidrak, for he was probably a much younger contemporary of Azarquiel, but that he also mentions the names of several of Ibn Barghüth's students who lived during the same period and who could have authored such a text themselves.

Since Ibn Barghūth's observations were explicitly mentioned by the later Ibn al-Hā'im as being used in conjunction with those of Azarquiel for the construction of astronomical handbooks, his students would then stand an excellent chance of being considered for the authorship of the Istidräk. These eleventh-century astronomers, who are mentioned by the various sources, included al-Wāsitīi, Ibn Shahr, al-Afțas al-Marwān̄̄, Ibn al- 'Ațțār, Abū 'Umar Ibn Mahdī, and Khālid b. Muhammad b. 'Abd Allāh b. Zayd, all of whom were working in the same circle which was close to Azarquiel, and any of whom could have been the sought-after author. Unfortunately, the same sources that identify these astronomers as students

\footnotetext{
${ }^{20}$ Arabic Ms, Marsh 618, containing al-Zīj al-Kämil fï al-Ta'ätīn of Abū Muhammad 'Abd alHaqq al-Ghāfiqī al-Ishbīlī, known as Ibn al-Hā'im. The manuscript is foliated by various hands that makes reference to it rather difficult. Of the physical folios that exist, folio $71 \mathrm{r}$ contains a reference to the date of composition as being the beginning of the seventh hundred year of Hijra, that is, around 600 A.H. (1203/1204 AD), and that is repeated in the colophon.

${ }^{21}$ Fol. 4r of the same Oxford manuscript, Marsh 618.

${ }^{22}$ Fol. 3v et passim.
} 
of Ibn Barghūth do not specify the titles of the books which were authored by them. And thus we are still at a loss regarding the authorship of al-Istidräk.

Although there is no concrete evidence that any of these persons was indeed the author of al-Istidräk which has not been found yet or Risälat al-Hay'a of Hyderabad, they are all suspects, so to speak, and none of them is yet on the "Most Wanted" list. To complicate the problem further, the reader should be warned that since medieval Arabic biographical sources tend to favor those who dabbled in religious sciences much more than those who worked on such esoteric subjects as astronomy, the likelihood of finding any more information about the works of these astronomers is very slim indeed, except for the case of Ibn Barghüth himself, for he was identified by Ibn al-Hā'im as a legal scholar (faqih) and a judge ( $q \bar{a} d \bar{l} \bar{l}$ ).

Returning to the text of Ibn al-Hā'im itself, i.e., his Kitāb al-Kämil, we find that it gives us more hope than was originally thought but not enough to settle the identity issue completely. What is does, however, is to point to the direction that future research should follow. It was already stated that Ibn al-Hā'im mentioned several astronomers in his book besides Ibn Barghüth. One of them was the practicing astronomer Abū Marwān al-Istijjī, ${ }^{23}$ who apparently left several observations that were used by later astronomers. According to Ibn al-Hā'im this Abū Marwān was supposed to have authored a text on the theory of trepidation, i.e., a text similar to that of Azarquiel, which must have attempted to explain the contradiction between the observations and the received Greek tradition of astronomy as encoded in Ptolemy's Almagest. People working in this area of trepidation could at the same time be excellent candidates for the kind of critique of Greek astronomy the Kitäb al-Istidräk may have contained.

What is more significant in the work of Ibn al-Hā' im, however, is that it referred at least twice to the notion of al-Istidräk hence bringing into focus the importance of the eleventh-century anonymous astronomer, the legacy that he must have left behind, and the sense in which the term istidräk itself was later used in al-Andalus to signal objections to Ptolemaic astronomy. This not only confirms that a book called al-Istidrak may have indeed existed in al-Andalus, but that the kind of subjects which were raised in that book formed an astronomical tradition of their own. The reason why this could easily be the case will soon become very clear.

The argument is based on the context in which Ibn al-Hā'im refers to the notion of istidrak. The first time he mentioned such a concept was in the introduction to his book, al-Kämil, where he listed first all the problems that he had found in the works of al-Kammād (ostensibly the reasons for which he

${ }^{23} \mathrm{Al}$-Kämil, fol. $4 \mathrm{r}$, or al-Istijjī, fol. $8 \mathrm{v}$. 
undertook to write his own book, al-Kämil as was just stated), and where he said at the end of that list: "And all that we recorded in this book by way of motions and other things that were taken in objection to the ancients (al-mustadraka' ala $a l$-qudamä) were all based on the observations of Abū Isḥāq Azarquiel may God have mercy on him". ${ }^{24}$

In this instance I understand Ibn al-Hā'im to refer to a tradition where several problems connected with Greek astronomy, here referred to as that of the ancients, were already identified, and that astronomers of his caliber would no longer take Greek astronomy at face value without referring to these problems which were incorporated in it. The fact that Ibn al-Hā'im uses the term mustadraka, here translated as objection, is significant for it has the same root as the term istidräk which was used by the eleventh-century anonymous author and in the title of his book on the same subject. By Ibn al-Hā'im's time, one can say that the problems of Greek astronomy were already grouped, as had also happened in the eastern part of the Muslim world, i.e., biläd al-Mashriq, where such problems were referred to as Ishkalät (Difficulties). The significance of this remark does not only confirm such developments in al-Andalus, but it also shows that there was a continuity between the tradition of al-Andalus and that of the eastern part of Islam.

The second time the notion of istidräk was mentioned by Ibn al-Hā'im is in the context of the description of the lunar motion, just as it was stipulated in the Hay'a text of Hyderabad mentioned above. In the words of Ibn al-Hā'im, after he had completed the description of the lunar motions, he said: "As for the additional thing which is taken in objection to the ancients (al-ziyäda al-mustadraka 'alä alqudam $\vec{a}$ ) in these anomalies it is as we shall mention in the sequel, with the help of the almighty God. And that (addition) is that the mean motion of the moon which is recorded in all the astronomical handbooks is based on the uniform motion of the lunar epicyclic center which is always around the center of the world". ${ }^{25}$

This is precisely the objection which was supposed to have been raised against the lunar configuration in Ptolemaic astronomy by the author of alIstidrak. It is also the same objection which was raised in the Mashriq by Ibn alHaytham in his famous Shukuk during the same century. This instance also points to the continuity between the east and the west of the Muslim world.

${ }^{24} \mathrm{Al}$-Kämil, fol. $9 \mathrm{r}$.

${ }^{25}$ See folio $42 \mathrm{v}$. I am led to believe that this specific section of the work of Ibn al-Hä'im is now discussed in a forthcoming study by Roser Puig Aguilar with the tentative title: "Theory of the Moon in the al-Zīj al-Kämil fíal-Ta 'altìn of Ibn al-Hā'im» (I owe this reference to J.Samsó and R. Puig). 
More importantly, it should be noted here that this objection was raised against Ptolemaic astronomy on the ground that it lacked the consistency between its own physical presuppositions and the mathematical language used by Ptolemy to describe the motions stipulated in his astronomy. This was not just philosophy; it may very well be philosophy of science. And this is especially significant in light of the commonly held opinion being refuted here that such objections were raised in the Mashriq only but not in al-Andalus.

From a different perspective, this debate with Greek astronomy illustrates very well the level at which the critical spirit mentioned above was already so well stablished in the land of al-Andalus. The fact that this critical approach to tradition was so commonly known in al-Andalus that it was mentioned in general unspecified terms by Ibn al-Hā'im further confirms the need to reexamine the astronomical works that were written in al-Andalus, and not to restrict the research on the criticism of Ptolemaic astronomy to the philosophical works only. Only then could the full range of the Andalusian critical tradition be fully understood. Some of those astronomical works have already been identified, and some have already been studied, but more needs to be done in that area. One can only note here the names of the astronomers who worked in the same critical tradition, but their works cannot be discussed in any detail at this point awaiting further analysis.

In this regard the famous work of Jābir Ibn Aflah should be mentioned. This astronomer has left a book which was translated into Latin and was printed several times during the early Renaissance, in which he took Ptolemaic astronomy to task on several points of an extremely sophisticated nature, all dealing with problems of scientific consistency. It was these problems that became very well known in the Latin west, and which must have detracted from the adequacy of Ptolemaic astronomy, a detraction that finally led to its downfall. Incidentally, despite its fame, Jābir's work still awaits a proper critical edition, both in Arabic and in Latin.

On the level of the spread of this critical tradition among the various communities of al-Andalus in Islamic times and in relationship to the tradition of the eastern part of the Muslim world, one should also mention the report preserved by al-Qiftī in his Ta'rikh al-Hukamä, ${ }^{26}$ and later abridged by Ibn al'Ibrī (Barhebraeus) in his work Mukhtasar al-Duwal. ${ }^{27}$ In it, al-Qiftī said that the 393.

${ }^{26}$ Jamāl al-Dīn 'Alī b. Yūsuf al-Qifțī, Ta'rikh al-Hukamā', ed. Julius Lippert, Leipzig, 1903, 392 -

${ }^{27}$ Abū al-Faraj Ibn al-'Ibrī, Tārikh Mukhtașar al-Duwal, ed. Antoun Șālḥānī S. J., Beirut: Dār alRā'id al-Lubnānī, photooffset of the 1890 edition, 423-424. 
famous Andalusian Rabbi Maimonides had to flee al-Andalus and to seek refuge in Egypt on account of the intolerance expressed by the Berber Muslim dynasties of al-Andalus against the Jews. While in Egypt, Qiftĩ reported that Maimonides read this same text of Jābir Ibn Aflah, which was brought along by one of his coreligionists, who sought the same refuge, by the name of Yūsuf $b$. Yahyā b. Isḥāq al-Sabtī al-Maghribī. Qifți went to say that this Yūsuf studied with Maimonides (qara'a 'alayhi) and that "he asked him to reform the astronomy of Ibn Aflah of al-Andalus, for he had brought it along with him from Sabta, and that he and Maimonides joined efforts to reform and verify it". It is indeed a tribute to Jābir Ibn Aflah that his book was brought along by someone fleeing persecution, but more importantly that he seemed to have inspired the desire for further reforms of Ptolemaic astronomy. ${ }^{28}$

Returning to the astronomical debate in al-Andalus, one should also mention the work of another Andalusian astronomer who wrote a long text in which he not only objected to Ptolemaic astronomy, but undertook the task of constructing an alternative to it. The astronomer in question is Nūr al-Dīn Bitrūjì (c. 1200) who wrote the text On the Principles of Astronomy, which was recently published by Bernard Goldstein. ${ }^{29}$ But that text should now be reassessed in light of its relationship to the philosophical tradition as well as to the tradition of mathematical astronomy that seems to have been initiated by the eleventh-century anonymous author. And one should also mention that this alternative astronomy of Bitruijī was also translated into Latin, and was known to astronomers of the Renaissance, including Copernicus.

\section{CONCLUSION}

By way of concluding it is important to note that the text of Ibn al-Hā'im is still important in yet another respect. In the context of discussing the exact length of the solar year, whether tropical or sidereal, Ibn al-Hā'im commended the earlier Muslim astronomers like Jābir Ibn Sinān al-Battānī (Latin Albategnius) who lived in the Mashriq towards the end of the ninth century and the beginning of the tenth, for admitting that the problem of precision is very difficult. Then he went on to say: «In summary, the majority of the learned were continuously in doubt

\footnotetext{
${ }^{28}$ Lest one thinks that all relations between Muslims and Jews were always that bad, let it be remembered that both of the above mentioned Jews took refuge in Egypt which was one of the most celebrated centers of Islam. It is not as if they fled to the Vatican or the like.

${ }^{29}$ Goldstein, B., Al-Bitrüji: On the Principles of Astronomy, New Haven: Yale, 1971.
} 
regarding the truth of this time (i.e., the solar year), and were in quandary and continuous confusion since old times until the Toledan Group (al-Jamä'at altulaytilizya) outdistanced all of them, especially Abū Isḥāq, may God's mercy be on all of them".

This simply says that eleventh-century Toledo was indeed a very active center in astronomy, and that the works conducted by those astronomers did indeed outmatch the works of the earlier astronomers. Among these innovative astronomers that are now known the names of Azarquiel and Ibn Barghūth stand out in this discussion. Future research should reveal the names and the importance of the others who were obviously intended with the term jama' $a$ (=group) and who may include among them the author of Kitäb al-istidräk.

For the purposes of this paper, I hope that I have managed to convince the reader of the vitality of this tradition which was obviously established during the eleventh century, and which apparently continued to grow from one Muslim Andalusian city to the next. I have maintained in this paper that the most important feature of the astronomical activities which took place during that period was the appearance of the most sophisticated tradition of criticism, which was very similar to and continuous with the tradition that was prevailing in the eastern domain of the medieval Muslim world. It is this spirit of criticizing the inherited Greek astronomical tradition, and the continuous attempts to reform it, which were bequeathed to the Renaissance of Copernicus. I also maintain that a proper understanding of this critical tradition is not only inevitable for the understanding of the development of Islamic astronomy in al-Andalus, but is also inevitable for the understanding of Copernican astronomy itself. Without this background of debate and criticism, and the role played by al-Andalus in that debate, the work of Copernicus would be historically inexplicable.

\begin{abstract}
This article announces the discovery of a hitherto unknown text called al-Istidräk by an anonymous eleventh-century Andalusian astronomer who was personally acquainted with Azarquiel and who has attempted to raise doubts concerning the Greek astronomical tradition. On the basis of this new evidence, the article argues against the oft-repeated characterization of the critical tradition in Islamic astronomy as being philosophical in alAndalus and more mathematical in al-Mashriq. Other evidence from both sides of the Mediterranean is brought to bear on the issue which also demonstrates the continuity between the two shores. The article stipulates that the fallacy in characterization has
\end{abstract}


stemmed from the false comparison between the works of philosophers in the west with those of astronomers in the east. When the works of astronomers from both sides were compared they revealed very clearly that the same problems motivated astronomical work all over the Islamic world. What also became clear is that eastern astronomers, like Ibn alShậtir of Damascus, were also deeply aware of the philosophical issues that preoccupied the Andalusian philosophers and managed to respond to them directly with some ingenious philosophical insights of their own.

\section{RESUMEN}

Este artículo presenta el descubrimiento de un texto hasta ahora desconocido, llamado Al-istidrak, obra de un astrónomo anónimo andalusí del siglo XI que conoció personalmente a Azarquiel y que planteó sus dudas acerca de la tradición astronómica griega. Sobre la base de este nuevo texto, el artículo pone en cuestión la idea que se ha venido manteniendo de que la tradición astronómica islámica fue sobre todo filosófica en al-Andalus y más matemática en Oriente. Se aducen además datos de ambos lados del Mediterráneo que demuestran que hubo una continuidad y unos contactos entre los dos extremos. El artículo mantiene que la falacia en esta caracterización de la astronomía islámica proviene de una falsa comparación entre las obras de filósofos occidentales con la de astrónomos orientales; cuando se comparan las obras astronómicas del Este y del Oeste queda claro que fueron los mismos problemas los que se plantearon en obras astronómicas en todo el orbe islámico. También se hace evidente que astrónomos orientales como Ibn al-Shạtir de Damasco estaban sensibilizados a las mismas cuestiones filosóficas que preocupaban a los filósofos andalusíes y respondieron a estas cuestiones con sus propias respuestas filosóficas. 